УДК 373.3.091.33

DOI: $10.35619 /$ iiu.v1i10.167

\author{
Козак Людмила \\ доктор педагогічних наук, доцент, \\ професор кафедри дошкільної освіти \\ Київського університету імені Бориса Грінченка, \\ м. Київ, Україна \\ ORCID: 0000-0002-4528-1905 \\ e-mail:l.kozak@kubg.edu.ua
}

Луцик Тетяна

магістрантка спеціальності «Дошкільна освіта» Київського університету імені Бориса Грінченка,

м. Київ, Україна

ORCID 0000-0003-1518-073X

e-mail:T.Lutsik@i.ua

\title{
ХАРАКТЕРИСТИКА ПЕДАГОГІЧНИХ ІННОВАЦІЙ У РОБОТІ 3 ДІТЬМИ ДОШКІЛЬНОГО ВІКУ
}

\begin{abstract}
Анотація. У статті висвітлено актуальність питання використання педагогічних інновацій у роботі 3 дітьми дошкільного віку; доведено, що сучасним дітям застосування нових технологій, методів та форм навчання й виховання необхідне задля полегшення отримання знань, умінь та навичок; наголошено на необхідності організації навчання через гру; проаналізовано наукові дослідження стосовно питань застосування педагогічних інновацій у роботі 3 дітьми дошкільного віку; розкрито зміст понять інновації та педагогічні інновації; охарактеризовано особливості інноваційних методів і форм навчання та виховання дітей; подано характеристику педагогічних інновацій в галузі дошкільної освіти; визначено найбільш використовувані інноваційні методики, технології, програми розвитку дошкільників; представлено закордонний досвід використання інновацій, охарактеризовано нововведення в закладах дошкільної освіти різних країн; показано, що системи дошкільної освіти за кордоном мають свої особливості та власний перспективний досвід; встановлено, що спільним для дошкільних закладів європейських країн $\epsilon$ особлива увага до створення розвивального середовища та організація різних видів діяльності, що сприяють загальному розвитку дитини, підготовці іiї до життя та навчання в школі.
\end{abstract}

Ключові слова: дошкільна освіта, дошкільний вік, інновації, педагогічні інновації, LEGO education, STEAM навчання, дошкільник, нововведення, розвиток, методика, технологія.

Постановка проблеми. Сучасне суспільство ставить досить високі вимоги до освіти дітей, особливо - дошкільного віку. На освітніх форумах, педагогічних семінарах-практикумах, виставках щорічно презентуються нові методики навчання та виховання дітей. Застосування педагогічних інновацій, які спрямовані на навчання через гру, у роботі з дітьми дошкільного віку необхідне для того, аби не перевантажувати дітей. Граючись, дитина одночасно отримує нові знання, використовує уже набуті та відпочиває.

Дошкільний вік - це період у житті кожної особистості, який є найважливішим, адже саме в цьому віці формуються вміння та навички дитини, іiі характер. У період дошкільного віку дитина вбирає інформацію, немов «губка»: вона відтворює будь-який звук чи дію, повторюючи за дорослим. 
Упродовж останнього десятиліття серед інновацій в освіті виокремлюють: ейдетику як засіб розвитку пам'яті та образного мислення у дітей; LEGO education навчання за допомогою конструкторів за спеціально розробленими методиками; комп'ютеризацію навчального та виховного процесу, STEAM навчання та інші. Також важливим аспектом вважається запровадження інклюзивного навчання.

Для того, аби педагогічні інновації працювали на користь, педагог повинен розуміти сутність методики чи технології, знати, коли ії можна застосувати та 3 дітьми якого віку.

Аналіз останніх досліджень 3 проблеми. Багато науковців приділяли значну увагу обгрунтуванню теоретичних аспектів дослідження інновацій, розкриттю основних понять (інновація, нововведення, інноваційний процес), структурі інноваційного процесу, виділенню етапів впровадження інновацій в умовах певної освітньої діяльності. Вищезгадані питання досліджували В. Загвязинський, В. Кремень, М. Кларін, А. Лоренсов, В. Ляудіс, М. Поташник, А. Хуторський, Н. Юсуфбекова та інші. Проблему педагогічних інновацій в освіті досліджують I. Дичківська, О. Дубасенюк, Л. Козак, К. Крутій, Л. Машкіна, О. Савченко, С. Сисоєва та інші.

Мета статті. Висвітлити актуальність питання інновацій у галузі дошкільної освіти; охарактеризувати особливості інноваційних методів і форм навчання та виховання дітей дошкільного віку.

Виклад основного матеріалу дослідження. Інновації в освіті $€$ закономірним явищем, динамічним за характером і розвивальним за результатами, їх запровадження дозволяє вирішити суперечності між традиційною системою і потребами в якісно новій освіті (LEGO education).

Інновації - новостворені (застосовані) і (або) вдосконалені конкурентоздатні технології, продукція або послуги, а також організаційно-технічні рішення виробничого, адміністративного, комерційного або іншого характеру, що істотно поліпшують структуру та якість виробництва і (або) соціальної сфери (Закон України «Про інноваційну діяльність», ст. 1).

Педагогічна інновація розглядається як процес реалізації конкретною особою (або групою осіб) ідеї, яка $є$ для неї (них) у цей час новою в навчально-виховному процесі, у результаті якого виникає творчий пошук оригінальних, нестандартних рішень (Визначення педагогічної інновації та педагогічної технології; перелік інновацій).

Однією 3 найвідоміших та інноваційних на сьогодні методик навчання дітей дошкільного віку є LEGO education - навчання дітей через гру.

Програма «ЛЕГО-конструювання» створена для розвитку конструктивних здібностей у дітей віком від 3 до 6 років засобами наборів конструктора LEGO Education і має на меті інтелектуальний, фізичний, емоційно-ціннісний та креативний розвиток дошкільників (LEGO education).

Навчання конструюванню сприяє розширенню словника, збагаченню дитячого мовлення. Виконуючи конструктивні дії, аналізуючи об'єкти, плануючи свою діяльність чи підсумовуючи ії, дитина засвоює потрібні слова, вправляється у правильному їх вживанні.

STEAM навчання - це поєднання різних дисциплін в межах вивчення чи опрацювання однієї теми (STEAM навчання).

Зважаючи на те, що сучасних дітей важко чимось зацікавити у навчанні, саме такий спосіб навчання забезпечує всебічний розвиток дитини, зацікавлює та мотивує до відкриття чогось нового, експериментів, отримання нових знань.

Серед педагогічних інновацій все частіше з'являються авторські методики навчання та виховання дітей дошкільного віку. Авторами цих методик найчастіше $\epsilon$ педагоги закладів дошкільної освіти, батьки, викладачі педагогічних вищих навчальних закладів. Однією 3 таких є авторська методика «Розглядай та пізнавай» 3 урахуванням індивідуальних особливостей і вікових можливостей кожної дитини 
I. Є. Товкач. Автор наголошує, що «працювати з книжкою, так само, як і гратися, можна лише тоді, коли цього хоче сама дитина! I починати таку роботу варто 3 «чарівного» для кожного малюка слова: «Пограймося!». Якщо дитина погоджується, тоді продовжуйте: «Один, два, три. Почали!»"» (Товкач, 2015, с. 9).

Для розвитку мовлення дітей дошкільного віку науковці К. А. Крутій та Н. В. Гавриш пропонують використання методики коректурних таблиць.

Коректурні таблиці - це інформаційно-ігрове поле з різною кількістю клітинок (від 9 до 25), заповнених предметними картинками (цифрами або буквами; цифрами і буквами; символами чи знаками, геометричними фігурами). Картинки добирають за змістом тематично. Тематична палітра коректурних таблиць може бути досить широкою. Вона майже не змінюється в різних вікових групах, розширюється лише змістове наповнення та урізноманітнюються зв'язки між елементами теми.

Під час роботи 3 коректурними таблицями основними завданнями для дітей $\epsilon$ такі: знайти правильну відповідь, назвати потрібне слово/слова, пояснити свої дії, висловити власну думку (коректурні таблиці за методикою К. Крутій та Н. Гавриш).

Педагоги-практики розробляють авторські технології, які поєднують у різних варіантах елементи апробованих технологій. Як правило, всі вони зорієнтовані на реалізацію змісту і досягнення мети різнорівневого і різнопрофільного навчання. Вихідним матеріалом для розроблення технології $\epsilon$ теорії, концепції. Багато педагогічних технологій мають у своїй основі такі концепції засвоєння соціального досвіду:

1) асоціативно-рефлекторне навчання, у межах якого розроблена теорія формування понять;

2) теорія поетапного формування розумових дій, згідно з якою розумовий розвиток (як і засвоєння знань, умінь, навичок) відбувається поетапно, спрямовуючись від «матеріальної» (зовнішньої) діяльності у внутрішній розумовий план;

3) сугестопедична концепція навчання, яка обгрунтовує комплексне використання у навчальних цілях вербальних і невербальних, зовнішніх і внутрішніх засобів сугестії (навіювання), що сприяє надзапам'ятовуванню;

4) теорія нейролінгвістичного програмування (НЛП), що розглядає процес навчання як рух інформації через нервову систему людини;

5) теорії змістового узагальнення, в основу яких покладено гіпотезу про провідну роль теоретичного знання у формуванні інтелекту дитини (Використання інноваційних технологій у роботі з дітьми дошкільного віку).

Все частіше сучасні заклади дошкільної освіти запозичують досвід своїх іноземних колег у роботі з дітьми дошкільного віку.

Одним із поширених методів у навчанні дітей іноземним мовам $є$ метод повної фізичної реакції (TPR). Метод TPR допомагає навіть дітям 2-3 років швидкому, ефективному запам'ятовуванню, а у старшому віці цей метод сприяє активізації мовлення дітей. Наш досвід використання посібників різних іноземних авторів на заняттях 3 іноземних мов у закладі дошкільної освіти свідчить про активне використання цієї методики протягом усього курсу навчання. На кожному занятті використовуються пісні, історії, казки, ігри, римівки, діалоги та ін. (В'юнник, 2019).

Усне рахування Соробан - найкраща розвивальна методика для дітей дошкільного віку. Це унікальна програма, створена з урахуванням особливостей психології та фізичного розвитку дітей, специфіки дитячого сприйняття інформації.

Програма навчання умовно розділена на 2 етапи. На першому - дитина вчиться рахувати на кісточках спеціальної рахівниці - абакусі обома руками одночасно. За допомогою абакуса засвоюються основні математичні операції.

На другому етапі навчання переходить на ментальний рівень. Поступово дитина відвикає від рахівниць. Усі розрахунки проводяться на уявному абакусі. Вже за кілька місяців після початку навчання діти $з$ легкістю вивчають іноземні мови, обчислюють 
про себе 10-цифрові числа, швидко вчать напам'ять вірші та прозу (Сучасна методика розвитку для дошкільнят).

Ще однією методикою розвитку дошкільнят $є$ методика Сесіль Лупан. За цією методикою діти виконують ті завдання, які хочуть. Як наочний посібник використовується все, що $є$ під рукою. Завдання дорослого - в цікавій формі ознайомити малюка $з$ усім, 3 чим він стикається. Не варто боятися, що дитина не зрозуміє значення якогось терміну. Головний принцип: $\epsilon$ знання - буде розуміння (Використання інноваційних педагогічних технологій у закладах дошкільної освіти).

Аналізуючи сучасні методики і технології, які впроваджуються у закладах дошкільної освіти в Україні, ми виокремили найбільш використовувані, серед яких:

- «Дитяче дослідження як метод навчання старших дошкільників» (А. Савенков): Програма дослідницького навчання в дошкільному закладі за А. Савенковим включає три елементи: розвиток у дітей дослідницьких умінь і навичок; дитячу дослідницьку практику; моніторинг дослідницької діяльності дошкільнят.

- «Вчіться фантазувати» (Н. Єгорова): Програмою передбачені творчі домашні завдання, розраховані на спільну діяльність дітей і батьків (дитина розповідає - батьки записують). Це позитивно впливає на відносини у сім'ї. Завдання розподілені на групи (пори року): зима, весна, літо, осінь. Кожна група завдань складається 3 таких: гра 3 використанням предметних карток; самостійне придумування та обговорення казки; розповідь-фантазія на вільну тему; психогімнастика; малюнок-ілюстрація до казки чи оповідання; відгадування загадок, придуманих дітьми. Домашнє завдання - розповіді батькам самостійно придуманої історії від імені казкового персонажа. Завдання батькам - записати розповідь у зошит (Використання інноваційних педагогічних технологій у закладах дошкільної освіти).

- «Друдли» (Р. Прайс): Друдли - головоломки для розвитку. Друдли - це картинка-головоломка, дивлячись на яку, треба придумати якомога більше схожих на неї речей, предметів, об'єктів чи явищ (Стеценко, 2019).

- «Кольорові долоньки» (І. О. Ликова): Мета програми - формування у дітей раннього й дошкільного віку естетичного ставлення й художньо-творчих здібностей в образотворчій діяльності (Ликова, 2019).

Одним із перспективних методів у сучасній дошкільній освіті $є$ метод проектної діяльності. Він дає змогу виховати «діяча», а не «виконавця», розвивати вольові якості особистості, формувати навички партнерської взаємодії.

3 точки зору педагога проектна діяльність в ЗДО хороша тим, що припускає самостійну діяльність дітей, в результаті чого вони вчаться відшукувати i використовувати в своїх цілях необхідну інформацію. Крім того, так дитина отримує можливість перетворення «сухих» і невиразних даних в практичний досвід, який цілком може допомагати їй упродовж усього життя.

Суть технології проектної діяльності в ЗДО полягає в такій організації освітнього процесу, при якій діти з бажанням отримують теоретичні та практичні знання, беруть участь у заходах творчого плану, а також вирішують постійно ускладнені завдання найрізноманітнішого характеру.

Будь-який проект обов'язково повинен мати не тільки пізнавальну, а й прагматичну цінність. Дитина повинна знати, які конкретно дані вона отримує, і де зможе їх використовувати на практиці. Це $\epsilon$ основною тезою технології проектної діяльності в ЗДО. Сьогодні такої точки зору дотримуються практично всі сучасні освітні установи, які намагаються відшукати розумний баланс між отриманням практичних і теоретичних знань (Гарькава, 2019).

Аналіз зарубіжного досвіду засвідчив, що всі розвинені країни світу намагаються застосувати якомога більше дієвих та нових методик навчання i виховання у дошкільній освіті. Аналізуючи методи навчання і виховання дітей дошкільного віку, нами визначено, що до інноваційних творчих методів у фізичній культурі в дошкільних закладах у Польщі відносять: Метод рухової експресії Карла Орфа, Метод 
ритмічної гімнастики Альфреда і Марії Кнєсув, Метод розвиваючого руху Вероніки Шерборне, Освітня кінезіологія Паула Деннісона, Метод Маріанни та Крістофера Кнулув, Метод рухової розповіді Юзефа Готфріда Туліна, Метод Еміля ЯгусаДалцрозе, Метод активного слухання музики Батті Штраус, Освіта через рух Дороти Джамскої.

У закладах дошкільної освіти Польщі практикують й інші інноваційні педагогічні методи. Найпоширенішими та дієвими $є$ такі: Метод драми, Метод байкотерапії, Метод релаксаційної казки, Метод психоосвітньої казки, Метод психотерапевтичної казки, Метод музикотерапії, Метод релаксації, Тренінг Якобсона, Автогенний тренінг Шульца, Метод формування особистої позитивної картини за Максвелом Мадцом, Метод масажу Марти Богданович, Тренінг творчої візуалізації, Метод проектів, Конструювання ігор, Нейролінгвістичне програмування, Метод сенсорної інтеграції Жана Ауреса (Лугіна, 2012, с. 182-183).

3 часом інновації, що виникли раніше, інтерпретуються, удосконалюються та 3'являються зовсім нові технології навчання та виховання. Це пов'язано зі стрімким розвитком суспільства та $з$ його потребами.

Висновок і перспективи подальших розвідок. Питання педагогічних інновацій в галузі дошкільної освіти залишається актуальним та мало дослідженим. Використання інновацій у закладах дошкільної освіти забезпечує впевнений крок уперед, адже діти це наше майбутне і ми повинні зосереджувати свою увагу на всебічному розвитку особистості відповідно до вимог сучасного суспільства. Сьогоднішні дошкільнята потребують інтегрованого, цікавого навчання, яке забезпечується використанням інноваційних технологій, форм, методів, засобів навчання і виховання. 3 кожним днем у світі зростає кількість новинок, серед іншого, і в галузі дошкільної освіти. Тому кожен педагог повинен бути обізнаним з інноваціями, розуміти та вміти застосувати їх у професійній діяльності.

Проведене дослідження не вичерпує всіх аспектів зазначеної проблеми. Подальшого дослідження потребують умови та процеси підготовки майбутніх вихователів до впровадження педагогічних інновацій у дошкільній освіті.

\section{СПИСОК ВИКОРИСТАНИХ ДЖЕРЕЛ}

LEGO education. [online]. Режим доступу: https://education.lego.com/en-us/about-us [Дата останнього звернення: 12.09.2019].

Закон Украйни «Про інноваційну діяльність» [online]. Режим доступу: https://zakon.rada.gov.ua/laws/show/40-15/ed20121205/find/sp:wide-?text=\%B2\%ED $\% \mathrm{ED} \% \mathrm{EE} \% \mathrm{E} 2 \% \mathrm{E} 0 \% \mathrm{~F} 6 \% \mathrm{~B} 3 \% \mathrm{BF}$ [Дата останнього звернення: 27.09.2019].

Визначення педагогічної інновації та педагогічної технології; перелік інновацій. [online]. Режим доступу: https://pidruchniki.com/16980303/pedagogika/viznachennya_ pedagogichnoyi_innovatsiyi_pedagogichnoyi_tehnologiyi_perelik_innovatsiy_[Дата останнього звернення: 17.09.2019].

STEAM навчання. [online]. Режим доступу: https://innovationhouse.org.ua/statti/osvitastem-i-steam-dodajte-trohi-tvorchosti-do-nauki/ [Дата останнього звернення: 17.09.2019].

Товкач, І. (2015). Працюють всі навколо нас: навч. посіб. Для дітей ст. дошк. віку. Київ: Грамота. 96 с. (Серія «Розглядай та пізнавай»).С. 9

Коректурні таблиці за методикою К. Крутій та Н. Гавриш. [опline]. Режим доступу: https:/vseosvita.ua/library/korekturni-tablici-za-metodikou-kkrutij-ta-ngavris62636.html [Дата останнього звернення: 25.09.2019].

Використання інноваційних технологій у роботі з дітьми дошкільного віку. [online]. Режим доступу: http://www.dnz228.edukit.zp.ua/metodichna _skarbnichka/vikoristannya_innovacijnih_tehnologij_v_robotu/ [Дата останнього звернення: 25.09.2019].

В'юнник, В. О. Сучасні методи навчання дітей дошкільного віку іншомовного спілкування: від теоріі до практики. [online]. Режим доступу: 
https://www.psyh.kiev.ua/B'юнник_В.О._Сучасні_методи_навчання_дітей_дошкільного _віку_іншомовного_спілкування:_від_теорії_до_практики. [Дата останнього звернення: 17.09.2019].

Сучасні методики розвитку розумових здібностей дошкільнят. [online]. Режим доступу: https://smartum.com.ua/about_us/blog/mentalnaya-arifmetika/suchasni-metodikirozvitku-rozumovikh-zdibnostey-doshkilnyat/ [Дата останнього звернення: 20.09.2019].

Сучасна методика розвитку для дошкільнят. [online]. Режим доступу: https://soroban.ua/ua/blog/sovremennaya-metodika-razvitiya-dlya-doshkolnikov/ [Дата останнього звернення: 25.09.2019].

Використання інноваційних педагогічних технологій у закладах дошкільної освіти. [online]. Режим доступу: http://kievskiy-ruo.edu.kh.ua/navchaljnovihovnij_proces/doshkiljna_osvita/vikoristannya_innovacijnih_pedagogichnih_tehnologij_u_ doshkiljnih_navchaljnih_zakladah/ [Дата останнього звернення: 21.09.2019].

Стеценко, І. Подорож до краӥни друдлів, або Де ховаються друдли? [online]. Режим доступу: http://cabivosp.blogspot.com/2015/09/blog-post_45.html [Дата останнього звернення: 21.09.2019].

Ликова, I. Кольорові долоньки [online]. Режим доступу: http://melitopoldnz41.edukit.zp.ua/Files/downloads/\%D0\%9B\%D0\%B8\%D0\%BA\%D0\%BE\%D0\%B2\%D0 $\%$ B0\%20\%D0\%86.\%D0\%9E.\%20\%D0\%9A\%D0\%BE\%D0\%BB\%D1\%8C\%D0\%BE\%D1 $\% 80 \% \mathrm{D} 0 \% \mathrm{BE} \% \mathrm{D} 0 \% \mathrm{~B} 2 \% \mathrm{D} 1 \% 96 \% 20 \% \mathrm{D} 0 \% \mathrm{~B} 4 \% \mathrm{D} 0 \% \mathrm{BE} \% \mathrm{D} 0 \% \mathrm{BB} \% \mathrm{D} 0 \% \mathrm{BE} \% \mathrm{D} 0 \% \mathrm{BD} \%$ D1\%8C\%D0\%BA\%D0\%B8..docx [Дата останнього звернення: 18.09.2019].

Гарькава, Ю. Проектна діяльність в ДНЗ. Технології проектної діяльності в ДНЗ. [online]. Режим доступу: https://mkdi.jimdo.com/атестація/проект/ [Дата останнього звернення: 18.09.2019].

Лугіна, О. (2012). Польські інноваційні педагогічні системи виховання та навчання дітей-дошкільників. Збірник наукових працьь. Частина 3. с. 179-184. [online]. Режим доступу: http://irbis-nbuv.gov.ua/cgi-bin/irbis_nbuv/cgiirbis_64.exe?C21COM=2\&I21DBN $=U J R N \& P 21 D B N=U J R N \& I M A G E \_F I L E \_D O W N L O A D=1 \& I m a g e \_f i l e \_$name $=P D F / z n p u$ dpu_2012_3_27.pdf [Дата останнього звернення: 20.09.2019].

\section{REFERENCES}

LEGO education [LEGO Education] [online]. Rezhym dostupu: https:// education.lego.com/en-us/about-us [Data ostanoho zvernennia: 12.09.2019]. (in Ukrainian)

Zakon Ukrainy "Pro innovatsiinu diialnist" [The Law of Ukraine "On Innovation Activity"] [online]. Rezhym dostupu: https://zakon.rada.gov.ua/laws/show/4015/ed20121205/find/sp:wide-?text=\%B2\%ED\%ED\%EE\%E2\%E0\%F6\%B3\%BF [Data ostanoho zvernennia: 27.09.2019]. (in Ukrainian)

Vyznachennia pedahohichnoi innovatsii ta pedahohichnoi tekhnolohii; perelik innovatsii [Definition of Pedagogical Innovation and Pedagogical Technology; List of Innovations]. [online]. Rezhym dostupu: https://pidruchniki.com/16980303/ pedagogika/ viznachennya_ pedagogichnoyi_innovatsiyi_pedagogichnoyi_tehnologiyi_perelik_innovatsiy [Data ostanoho zvernennia: 17.09.2019]. (in Ukrainian)

STEAM navchannia. [STEAM Education]. [online]. Rezhym dostupu: https://innovationhouse.org.ua/statti/osvita-stem-i-steam-dodajte-trohi-tvorchosti-do-nauki/ [Data ostanoho zvernennia: 17.09.2019]. (in Ukrainian)

Tovkach, I. (2015). Pratsiuiut vsi navkolo nas: navch. posib. Dlia ditei st. doshk. viku [Everyone Around Us Works: textbook]. Kyiv: Hramota. 96 s. (Seriia "Rozghliadai ta piznavai"). s. 9 (in Ukrainian)

Korekturni tablytsi za metodykoiu K. Krutii ta N. Havrysh [Correction Tables Concerning to the Methodjlogy of K. Krutii and N. Havrysh]. [online]. Rezhym dostupu: https://vseosvita.ua/library/korekturni-tablici-za-metodikou-kkrutij-ta-ngavris-62636.html [Data ostanoho zvernennia: 25.09.2019]. (in Ukrainian)

Vykorystannia innovatsiinykh tekhnolohii u roboti z ditmy doshkilnoho viku. [The Use of Innovative Technologies in Work with Preschool Children]. [online]. Rezhym dostupu: 
http://www.dnz228.edukit.zp.ua/metodichna_skarbnichka/vikoristannya_innovacijnih_tehnol ogij_v_robotu/ [Data ostanoho zvernennia: 25.09.2019]. (in Ukrainian)

Viunnyk, V. O. Suchasni metody navchannia ditei doshkilnoho viku inshomovnoho spilkuvannia: vid teorii do praktyky [Modern Methods of Teaching Preschool Children of Foreign Language Communication: from Theory to Practice]. [online]. Rezhym dostupu: https://www.psyh.kiev.ua/Viunnyk_V.O._Suchasni_metody_navchannia_ditei_doshkilnoho_ viku_inshomovnoho_spilkuvannia:_vid_teorii_do_praktyky [Data ostanoho zvernennia: 17.09.2019]. (in Ukrainian)

Suchasni metodyky rozvytku rozumovykh zdibnostei doshkilniat [Modern Methods of Development for Preschool Children]. [online]. Rezhym dostupu: https://smartum.com.ua/about_us/blog/mentalnaya-arifmetika/suchasni-metodiki-rozvitkurozumovikh-zdibnostey-doshkilnyat/ [Data ostanoho zvernennia: 20.09.2019]. (in Ukrainian)

Suchasna metodyka rozvytku dlia doshkilniat [The Use of Innovative Pedagogical Technologies in Preschool Education Establishments]. [online]. Rezhym dostupu: https://soroban.ua/ua/blog/sovremennaya-metodika-razvitiya-dlia-doshkolnikov/ [Data ostanoho zvernennia: 25.09.2019]. (in Ukrainian)

Vykorystannia innovatsiinykh pedahohichnykh tekhnolohii u zakladakh doshkilnoi osvity [The Use of the Innovative Pedagogical Technologies in Preschool Establishments] [online]. Rezhym dostupu: http://kievskiy-ruo.edu.kh.ua/navchaljno-vihovnij_proces/ doshkiljna_ osvita/vikoristannya_innovacijnih_pedagogichnih_tehnologij_u_doshkiljnih_navchaljnih_za kladah/ [Data ostanoho zvernennia: 21.09.2019] (in Ukrainian)

Stetsenko, I. Podorozh do krainy drudliv, abo De khovaiutsia drudly? [Traveling to the Country of Friends, or Where are the Friends Hidden?]. [online]. Rezhym dostupu: http://cabivosp.blogspot.com/2015/09/blog-post_45.html [Data ostanoho zvernennia: 21.09.2019]. (in Ukrainian)

Lykova, I. O. Kolorovi dolonky [Colored Palms] [on line]. Rezhym dostupu: http://melitopol-dnz41.edukit.zp.ua/Files/downloads/ \%D0\%9B\%D0\%B8\%D0\%BA\%D0\% BE\%D0\%B2\%D0\%B0\%20\%D0\%86.\%D0\%9E.\%20\%D0\%9A\%D0\%BE\%D0\%BB\%D1\%8 C\%D0\%BE\%D1\%80\%D0\%BE\%D0\%B2\%D1\%96\%20\%D0\%B4\%D0\%BE\%D0\%BB\%D0 $\% \mathrm{BE} \% \mathrm{D} 0 \% \mathrm{BD} \% \mathrm{D} 1 \% 8 \mathrm{C} \% \mathrm{D} 0 \% \mathrm{BA} \% \mathrm{D} 0 \% \mathrm{~B} 8$. doc. [Data ostanoho zvernennia: 18.09.2019]. \{ in Ukrainian)

Harkava, Yu. P. Proektna diialnist v DNZ. Tekhnolohii proektnoi diialnosti v DNZ. [Project Activity in the State Educational Center. Technologies of Project Activity in Preschool Institutions]. [online]. Rezhym dostupu: https://mkdi.jimdo.com/atestatsiia/proekt/ [Data ostanoho zvernennia: 18.09.2019]. (in Ukrainian)

Luhina, O. Polski innovatsiini pedahohichni systemy vykhovannia ta navchannia diteidoshkilnykiv. [Polish Innovative Pedagogical Systems of Education and Education of Preschool Children]. V: Zbirnyk naukovykh prats. Chastyna 3, 2012 http://irbisnbuv.gov.ua/cgi

bin/irbis_nbuv/cgiirbis_64.exe?C21COM=2\&I21DBN=UJRN\&P21DBN=UJRN\&IMAGE_ FILE_DOWNLOAD=1\&Image_file_name=PDF/znpudpu_2012_3_27.pdf （s. 179-184） [Data ostanoho zvernennia: 20.09.2019]. (in Ukrainian) 


\title{
CHARACTERISTICS OF PEDAGOGICAL INNOVATION IN THE WORK WITH PRESCHOOL CHILDREN
}

\author{
Liudmyla Kozak \\ Doctor of Sciences (in Pedagogy), Associate Professor, \\ Professor at the Department of Preschool Education \\ Borys Hrinchenko Kyiv University, \\ Kyiv, Ukraine, \\ ORCID: 0000-0002-4528-1905 \\ e-mail:l.kozak@kubg.edu.ua \\ Tetiana Lutsyk \\ Undergraduate in Specialty "Preschool education" \\ Boris Hrinchenko Kyiv University, \\ Kyiv, Ukraine \\ ORCID: 0000-0003-1518-073X \\ e-mail:T.Lutsik@i.ua
}

\begin{abstract}
The article highlights the relevance of the issue of the use of pedagogical innovations in the work with preschool children; it is proved that modern children need to use new technologies, methods and forms of education and training in order to facilitate the acquisition of knowledge, skills and abilities; it is emphasized the necessity to organize learning through games; scientific researches on the issues of applying pedagogical innovations in work with preschool children have been analyzed/ The content of the concepts "innovation" and "pedagogical innovation" have been revealed; features of innovative methods and forms of education and upbringing children have been characterized; characteristics of pedagogical innovations in the field of preschool education have been presented.

The most used innovative methods, technologies, programs for the development of preschoolers have been identified in particular: eidetics, LEGO education, STEAM training, Consider and discover, Drudles, Soroban program, TPR method, Learn to fantasize, Color palms, Child research as a method of teaching senior preschoolers, Project activity, Cecil Lupan methodology, Proofreading tables; the foreign experience of using innovations was presented, innovations in preschool education institutions of different countries have been characterized/ It has been shown that preschool education systems abroad have their own peculiarities and their own perspective experience/ It has been found that special attention is paid to the creation of a developmental environment and the organization of various activities that contribute to the overall development of the child, preparation for life and education at school.

Keywords: preschool education, preschool age, innovation, pedagogical innovation, LEGO education, STEAM training, preschooler, novation, development, method, technology.
\end{abstract}

Стаття надійшла до редакиії 30.09.2019 p. 